\title{
The Paradox of Social Media: The De-democratization of Malaysia
}

\author{
Leo Agustino 1 \\ Badrul Azmier Mohamed@Bakar ${ }^{2}$
}

\begin{abstract}
Today, social media is perceived as "the media." Blogs and bloggers have changed journalism; YouTube has discovered rare and raw talents; and "the trinity" (Facebook, Twitter, YouTube) have sparked revolutions. Focusing on end-users instead of producers and its interactive-ness are two paramount characters that permit ordinary people to engage in extra-ordinary activities. From the showbiz to politics, social media has left its marks. The World political events in recent years, in particular Arab Spring of MENA (Middle East and North Africa) have showcased positive link between social media and democratization. Malaysia has experienced quite a similar phenomenon to MENA in the verge of the $12^{\text {th }}$ General Election (GE-12), held on March 8, 2008. The failure of the only ruling coalition, Barisan Nasional (National Front, or BN) to retain its two-third majority in the GE-12 is an empirical evident of people's desire and aspiration for free and fair elections, good-governance, and democratization which are very different from race-based politics. At a glimpse, the results of the $13^{\text {th }}$ General Election (GE-13) which was held on May 5, 2013 are quite similar to the GE-12. Yet, deeper analyses indicated race-base politics and "strong government" has made a comeback. Hence, this article explores the paradox when the state is not only interfering but also participating in social media. This exploration demonstrates social media is not only meant for the masses; and that by possessing money, machinery, and authority; the state is potentially dominant at social media.
\end{abstract}

Keywords: Democratization, de-democratization, social media, general election

\begin{abstract}
Abstrak
Saat ini, media sosial diterima sebagai "media". Blog dan para blogger mengubah jurnalisme: YouTube menemukan bakat-bakat terpendam dan alami; serta "the trinity" (Facebook, Twitter, YouTube) telah memicu revolusi. Fokus yang lebih diberikan kepada pengguna akhir ketimbang produsen dan karakter interaktifnya adalah dua karakter penting yang memungkinkan orang-orang biasa terlibat dalam aktivitasaktivitas yang tidak biasa. Dari pertunjukan ke politik, media sosial telah meninggalkan jejaknya. Peristiwa politik dunia dalam beberapa tahun terakhir, khususnya fenomena Arab Spring dari MENA (Timur Tengah dan Afrika Utara) telah menunjukkan hubungan positif antara media sosial dan demokratisasi. Malaysia mempunyai pengalaman yang hampir sama dengan fenomena MENA dalam Pemilihan Umum ke 12 (GE12), pada 8 Maret 2008. Kegagalan dari satu-satunya koalisi yang berkuasa, Barisan Nasional (National Front, or BN) untuk mempertahankan 2/3 suaranya adalah bukti empiris bahwa rakyat berkeinginan dan mempunyai aspirasi untuk Pemilu yang bebas dan adil, pemerintahan yang baik, dan demokratisasi yang sangat berbeda dari politik berbasis ras. Sekilas, hasil Pemilihan Umum 13 (GE-13) yang diselenggarakan pada 5 Mei 2013 sangat mirip dengan GE-12. Namun, analisis yang lebih dalam menunjukkan bahwa politik berbasis ras dan "pemerintah kuat" telah kembali. Oleh karena itu, artikel ini mengeksplorasi hal yang paradoks ketika negara tidak hanya mencampuri tetapi juga berpartisipasi di media sosial. Eksplorasi ini menunjukkan bahwa media sosial tidak hanya dimaksudkan untuk massa; dan bahwa dengan memiliki uang, mesin, dan otoritas; negara berpotensi menjadi dominan di media sosial.
\end{abstract}

Kata-Kata Kunci: Demokratisasi, de-demokratisasi, media sosial, pemilihan umum

${ }^{1}$ Dosen di Fakultas Ilmu Sosial dan Ilmu Politik, Universitas Sultan Ageng Tirtayasa (Untirta), Banten. Email: leoagustino@gmail.com

${ }^{2}$ Mahasiswa Doktoral di School of History, Politics, and Strategy, Faculty of Social Science and Humanities, Universiti Kebangsaan Malaysia (UKM), Malaysia. Email: badrulmohamed@yahoo.com 


\section{Introduction}

Social media and today's individuals have very special relationships. Many put priority on their gadgets more than their family and friends. The intimacy is portrayed through people's behavior. Occupying time by socializing with the gadgets like smart-phones and tablets instead of having real conversation at a dinner table with real human beings is a common social scene and gradually accepted as a norm. "The trinity", namely Facebook, Twitter, and YouTube are among the popular ones. The popularity of social media is a result of deepening internet penetration which is a part of the development in the information and communication technology (ICT). Prior to social media age, the access to the internet is limited to desktops and laptops. But nowadays, rapid development in ICT has permitted the Internet to be accessed via mobile gadgets like smart-phones and tablets. The progress has revolutionized the usage of social media in many sectors for different purposes. Since then, the process of disseminating and sharing information has been radically different. The process is fast, easy, and relatively cheaper. The technological advancements have also allowed social media to be accessed at anytime; anywhere. Like its traditional counterparts, the printed press, radio, and television; social media is getting political and henceforth, tremendously affecting politics and democracy.

Social media as a political tool has gained attention since after the success of Sarkozy in the $23^{\text {rd }}$ French Presidential Election held in May 2001. Sarkozy's campaign was armored with Facebook and Twitter. Across the Atlantic; occupying the White House after battling Clinton for the Democrat's candidacy and later defeating McCain, the $56^{\text {th }}$ U.S. Presidential Election has become another empirical evident to support a proposition of the ever-increasing roles of social media in democracy, and also democratization. Obama camp has successfully integrated technology in their campaign exercises by engaging the voters, in which the trinity (Facebook, Twitter, and YouTube) have played significant roles. Obama managed to gain the highest number of ballots in the history of U.S. Presidential Election. The success of the first African American to become the U.S. President is comparable to the success of John F. Kennedy, a Catholic. The way social media contributed to Obama's success is also comparable to the role of television during Kennedy's time. Apparently, the media, and currently the most trending is social media; have changed politicking and political landscape, not only in the U.S., but the world.

In the third world, or developing countries, social media has been utilizing by the dissidents of the semi-democratic states, or autocratic states. The dissenting voices have been operated in the form of people's movement, civil societies, or opposition 
parties. The most phenomena was the powerful force of social media in mobilizing street protests in such magnitude displayed during Arab Spring. The massive impact of Arab Spring has escalated the emergence of propositions and hypotheses that presume the positive relationship between social media and democratization. Prior to the people awakening in Arab countries, the region of MENA has witnessed "Green Revolution" or "Twitter Revolution" in Iran. The revolution is an expression of dissatisfaction of the Iranians; to be specific; the resentful people of Teheran towards the ballot-counting progress of the 2009 Iranian Presidential Election. The unofficial result showed Ahmadinejad was at the front with more than $63 \%$ of the ballots gone to him for his re-election for presidency. Shirazi (2010) convincingly described the role of social media in the revolution; Facebook organized the protest; Twitter coordinated the demonstration; and YouTube broadcasted to the world. The regime tight control onto traditional media during the unrest failed to curb the outflow of information from the Iranian border.

The falls of the old regimes of MENA have shocked the world. Ben Ali, Mubarak, and Gaddafi were very powerful, and revered by their people. Moreover, most of these autocratic republics had regimes that were close to pure sultanism (Stepan \& Linz, 2013:26-29). Hence, the democratization through mass revolution in hope for democracy had been unlikely to happen in the region which democracy has been an alien. Bellin (2004) listed out the factors why the region lacks the essence for both democratization, and democracy. MENA societies lack of strong civil society; grapple to crippling market-based economy; have low income and low literacy rate among its people; have un-democratic neighbors; and possess nearly no experience in democracy. However, Arab Spring has offered new perspectives of the Arab World and MENA to political science.

The mass protests sparked off in Tunisia on December 17, 2010 that made Bouazizi a worldwide household name. The nationwide protests forced Ben Ali to leave Tunisia to Saudi Arabia for asylum on January 14, 2011. The domino effect reached the Arab Republic of Egypt on January 25, 2011. The uprising in Egypt shared similarities to Tunisia especially its casus belli. Khaleed Saeed died in the hands of police brutality. Similar to the Iranian and Tunisian revolutions, social media was at the centre stage in mobilizing the series of street protests. The Arabs awakening in Egypt or Jasmine Revolution is considered the epitome of Arab Spring and the height of social media role in a revolution for democratization. The tale of a social media revolution is completed when the mass movement found a hero; a Dubai-based Egyptian Google's executive named Wael Ghonim who initiated a legendary Facebook page "We are all Khaleed Saeed." In short, 
Arab Spring has contributed to the emergence of thoughts or "beliefs" that proposed and hypothesized the positive relationship between social media and democratization.

\section{Background}

Social media has expanded the public sphere in Malaysia. Prior to the increase popularity of the trinity (Facebook, Twitter, and YouTube), political blogs and blogging have made substantial impact. The latter claims to be a part of democratization process in Malaysia which the GE-12 result as an empirical evident. In the GE-13, race-based ruling coalition; $\mathrm{BN}$ failed to maintain its twothird majority in the Parliament; and lost another 4 state governments to the opposition coalition, Pakatan Rakyat (People's Pact, or also known as PR) which already secured the state of Kelantan. The success of PR is determined by its liberal and democratic rhetoric such as good-governance, free and fair elections, fortification of check and balance through upholding the separation of power, egalitarian society, human rights, and human security. Hence, the outcomes of the GE-12 indicated growing desire and aspiration of multi-racial Malaysians shifting from the old politics of race to the new politics of democracy. The outcomes also precursor the people's changing preference from the strong government of the hegemonic one-party system to a democratic two-party system that upholds good-governance, the separation of power, and the check and balance. In another perspective, the GE-12 result was the outcome of the nearly no presence of the state or the ruling party in the virtual space of Malaysian social media.

In the verge of GE-13, BN was at the forefront at social media in comparison to PR. The simplest comparison but fundamental is between Prime Minister Najib Razak and Chief Opposition Anwar Ibrahim. During the period, Najib has more friends and followers than Anwar whether in Facebook or Twitter. At a glimpse, the results of the state participation in social media towards the GE13 are not different from the results of the absence of state participation (GE-12). However, a detail analysis on the results of the said election provides different findings. The society has been said to be more racially polarized than it used to. Hence, the situation poises two fundamental questions about the real outcomes of the state participation in social media. Firstly, is the participation of the state in social media promoting democratization or de-democratization? Second question; is social media just another media? Thus, the article is conceptually exploring the paradox of social media when the state is not only interfering but also participating in social media.

\section{Media and Democracy in Malaysia}

There are variations of terminologies that have been used to describe Malaysian democracy. "Repressive-responsive" and 
"neither authoritarian nor democratic" are two terms coined by Crouch (1996). "Syncretic state" (Jesudason 1996), “coerciveconsociationalism” (Mauzy, 1995), “authoritarian populism" (Kua 1995), "statist democracy" (Jesudason 1995); “semidemocracy" (Case 1993), "quasi democracy" and "illiberal democracy" (Zakaria 1989), and "democracy without consensus" (Von Vorys 1975) are the other terms referring to type of democracy in Malaysia. "Asian model" and "enlightened democracy" are the other two labels that fit to describe Malaysian democracy, in which the ruling elites symbolize stability and predictability (Kukeyeva \& Shkapyak 2013:80). Apparently, all the terms connotes the adoption of a model of strong government in Malaysia which also implicates the position of media and public sphere in the society. The stability of racerelations is the main justification of controlling the media. Hence, Malaysian citizens have never enjoyed free speech and expression like their counterparts in western countries particularly, the United States and the United Kingdom (Mohd Azizudin 2010:65).

Despite growing resentment towards available repressive laws by the people, most of the laws are still surviving. Amongst them are; Seditious Act 1948, Internal Security Act 1960 (ISA), University and College University Act 1971 (AUKU), Official Secrecy Act 1972 (OSA), and an act specific for the media is Publication and Press Printing Act 1984 (301
Act). Provision 6, Section III of 301 Act authorizes the Home Minister to review any publication permits which may be resulted to a renewal, adjustments to the terms of circulation, or a suspension, revocation, and awarding of license. A complimentary to the earlier, Provision 24, Section V of 301 Act protects Home Minister from any legal proceedings pursued by any media operators that experienced losses due to the rulings or law enforcement by the state. Apart from that, the state controls television and radio through state-ownership, and ruling-party's shareholdings. A national broadcasting agency, Radio Televisyen Malaysia (RTM) has been bureaucratically placed under the Ministry of Information, Communication, and Culture (Kementerian Penenerangan, Komunikasi, dan Kebudayaan). RTM operates two television channels and multiple radio stations. TV stations like TV3, NTV7, TV9, and 8TV are operated by Media Prima Berhad, a media giant which is closely linked to the ruling party. A similar explanation goes to Astro, a main satellite TV provider that monopolizes Malaysian subscribed-TV market.

In relation to democracy in Malaysia, the traditional media in particular, television, radio, and the printed media have provided a sphere to the state than to the public. The three control means; legal provisions, stateownership, and ruling-party shareholdings have exposed the media to the exploitation by 
the state especially during any elections, be it a general election or a by-election. A photo of Tengku Razaleigh (the Malaysian opposition leader in the late 80 's and the early 90 's) wears a Kadazan-Dusun sigah (a Sabah's ethnic headgear) which displays Christian-like cross is a classic example of media manipulation towards general election. Tengku Razaleigh was a prime minister hopeful. His newly formed political pacts; Gagasan Rakyat and Angkatan Perpaduan Ummah were anticipated to win 1990 General Election. The "unIslamic" photo appeared on national TV and posted in Malay newspapers one day before Malaysian voters casted their votes. The landslide majority secured by $\mathrm{BN}$ in 1990 General Election showcased the success of the media in manipulating primordial sentiments like race and religion in a multi-cultural society. The situation also shows that the traditional mainstream media has been serving the state by propagating propaganda and denying fair reporting to the opposition parties.

In response to the pressure for democratization, Malaysia has disembarked on Political Transformation Program (PTP) with the abolishment of ISA in 2012. PTP is one of the three transformation programs. The other two are; Government Transformation Program (GTP), and Economic Transformation Programs (ETP) initiated by Najib's administration. The programs demonstrate Najib's commitment to distant away from "the government knows all" attitude and dictatorial image of his predecessors mainly Mahathir. Paradoxically, the legislation of Public Assembly Act 2013 (PAA) shows that the political transformation is multi-faceted. Despite liberalizing the economy and the society, there have been concerted efforts to maintain status-quo which might lead to the de -democratization. The legislation also indicated growing concern of the state towards the increased demand for democratization that may potential remove the current government via un-democratic means like street revolution. Apart from replacing the roles of ISA, PAA compliments the functions of Communication and Multimedia Act 1998 (588 Act). Although 588 Act functions to close the gaps occurred in between the available laws; or serves as a state control enabler in relation to the virtual space, but the reality states the state has limited control over the Internet. Thus, the inability of the state to control social media (including through legal measures) led the enactment of PAA. Social media may exacerbate tensions, precipitate violence, and catalyze revolution; however PAA may have effectively distorted any orchestrated mobilization of the masses to the streets to protest.

\section{The emergence of Social Media in Malaysia}

The close relationship between social media and democratization in Malaysia is traceable to the era of reformasi (or reformation) which is a result of the 1997 Asian Financial Crisis. In Indonesia, the crisis 
caused the fall of Suharto, which opened avenues for democratization (Leo Agustino 2013). In Malaysia, the crisis caused the fall of Anwar, which also created paths for democratization. The revolutionary attribute of Indonesia's democratization is very different from Malaysia's process of democratization which has been slow, and at times, stagnant. Even though Malaysia's refomasi failed to produce any regime change, democracy has gradually penetrated into Malaysian political scene.

Prior to reformasi, Malaysia has undergone rapid economic development. Malaysia, just like many other East Asian countries has embraced developmental state (Sity 2004:28). In which the state not only intervenes but also participates actively in economy. The establishment of corporate nationalism; the existence of many government link companies (GLC's); and the foundation of the state's investment arms signify the prominent role of the state in economy. In the mid of 1990's Malaysia was hailed as one of the Asian Economic Tigers due to the years of miraculous economic growth. Malaysia was categorized together with Indonesia, Thailand, and the Philippines. The tigers closely tailgated the more advanced East Asian Economic Dragons or the NIC's (Newly Industrialized Countries) namely; South Korea, Taiwan, Hong Kong, and Singapore. Developmental state has assisted the shifting process of Malaysia's economy from agriculture-based into industry-based. The model of developmental state has adopted industrial-manufacturing-electronic-exportbased economy which is the result of the then successful global neo-liberal economic policies that involved liberalization, deregulation, and privatization. The development of the sector was largely due to the foreign direct investments (FDI) that attracted to the abundance of cheap labors in East Asia. Thus, the new economic model has increased economies interdependency and does not isolate Malaysia from the exposure of the world's volatile economic climate.

Oil and gas sector, state-initiated mega projects are not sufficient to complement manufacturing for sustainable economic growth. The expansion of middle class population has become a threat than a pride in a globalizing world. To develop further, Malaysia required diversifying its economic activities. Mahathir saw opportunities in ICT to accommodate Malaysia's changing society which then occupied by the increasing number of skilled labors. Multimedia Super Corridor (MSC) and Cyberjaya smart-city were based on Silicon Valley concept in California. Mahathir envisioned Malaysia as a hub for ICT -based industry of South East Asia. Unlike traditional media, the absence of the state is one of the most important determinants that characterized cyberspace. Thus, in attracting FDI for ICT industry, Malaysian government has no other alternative. As a result, the state 
promised to protect the anarchic ambience of virtual space. The promise was comparable to the United States' First Amendment (Tan 2010:30). The undivided commitment displayed the pragmatic character of the state that is willing to conform to the principles of liberal democracy to support economic development.

As a result, Malaysian virtual space in social media is congruent with Habermas' concept of public sphere. Members of community could collectively form public opinion in an ecosystem remote from the state and a market. Beers (2006:116) explained the ideal public sphere permits citizens to interact, study, and debate on the public issues without fear of reprisal from any political or economic powers. Therefore, since 1998 which depicts the fall of Anwar to 2009 that marks the inception of Najib administration, the state has been virtually absent from social media. When deemed necessary, the state chose to harass the actors of social media. Basically, within the mentioned period, the state has predominantly let the cyberspace to be "nearly" anarchy. The attitude offers a spacious public sphere for many political actors in Malaysia to involve in political discourse and political communication. Those who have been denied access offline have gone online. In addition, the audience who seek different types of information and alternative kind of reporting, browsing to the Internet and social media to fulfill their needs (Fischer 2009). Initially perceived as an alternative media, the Internet and social media have been steadfastly replacing the role of the traditional media.

In a span of 11 years, from 1998 to 2009 , the public sphere of social media has been politically used by non-state actors. The state has been mainly focusing on public service or e-government. Therefore, social media has been populated rapidly by the oppositions, civil societies, and individuals. There had been websites and blogs which had been vocal in criticizing the state. The intense popularity of blogs had attracted influential individual like the ex-premier Mahathir to blogging to voice out dissatisfaction towards Abdullah administration. Blogs provide the grounds for greater news frame parity, multiple perspectives and alternative interpretations of decisions and events (Touri 2009:181). Moreover, the emergence of Web 2.0 that permits two-way and real-time communication has created a politically democratic ecosystem in social media. Thus, political space in Malaysia can be clearly divided into two; traditional media as the state sphere; and social media as the public sphere. Free from selfcensorship, social media welcomes variation of political views and ideologies. Social media provides space for dissatisfactions and grievances. Hence, social media has become a platform that helped the emergence of an imagined community. The concept of imagine community mirrors; a community that is dissatisfied with existing political condition; 
unfriendly or skeptic towards the ruling elites; and connecting members using printed media, printed capitalism (Anderson 1983). Apparently, the Internet is the tool to support the creation and the existence of any imagined communities at cyberspace (Tan 2010:103104). In Malaysian context, this racially diverse community is imagining; the emergence of a better nation in favor of democratization; strongly advocating goodgovernance; and distant away from race-based politics.

One of the political events that resonates the role of social media in Malaysian democracy was the emergence of a Facebook page known as "1M Malaysians Against 100storey Mega Tower. Explicitly, the objective was to express the people's objection to the state's proposal to construct a mega tower, known as Menara Warisan. The proposal was presented to the public before the Parliament on October 15, 2010. The Facebook page became a phenomenon due to its immense popularity. For the first two weeks of its existence, more than 10 thousand Facebookers liked the page within a second. Towards the end of 2010, the page raised more than 260 thousands likes. The page administrator has repeatedly claimed that the page is nonpartisan. In Tunisia and Egypt, the Facebook pages had been used to mobilize street demonstrations (Gershman 2011:3). But in Malaysia, innovative virtual "street" demonstrations have been held few times via this page. The facebookers put up images of banners and posters that convey message of disagreements to the state. Social media has facilitated both extra-institutional (protests), and intra-institutional (elections) expression of political power (Mohd Azizuddin \& Zengeni 2010:6).

\section{State Participation in Social Media}

Obviously, the state participation in social media has characterized the GE-13. The political marketing exercise in social media by the state showcases the state pragmatic attitude in dealing with the internet. Unlike before, the sour relationship between the state and the internet has been marked by harassment that involves deployment of the state authorities. The action taken by the state depends on the seriousness, the scale, and the magnitude of damage brought by social media. However, in facing the GE-13 the state opted to participation in dealing with influential social media to secure votes instead of being confrontational. Najib has clearly learned the lesson that befriending to social media is more beneficial. The unprecedented result of GE-12 shows the outcome of the state negative and ignorant attitude towards social media.

Najib succeeded Abdullah in April 2009 due to poor performance of $\mathrm{BN}$ in 2008 GE-12. Since then, the attitude of the state towards social media has changed with the change of leadership. Since then Najib has been an active user of Facebook, Twitter, and 
Instagram. Social media allows a person with authority to appear as "real person" and nonthreatening (Marichal 2012:139). The prime minister have engaged the people especially the young ones via his hip status updates over Facebook, and micro-blogs his activities and whereabouts over Twitter. Tweeting a picture of him with Mark Zuckerberg and mentioning he is at Twitter headquarter is the most infamous whereabouts tweet of Najib in 2013. In 2010, Najib initiated a special engaging program for his virtual friends at Facebook. "Mari Berhubung Mari Bertemu" (MBMB) or "Lets Engage Lets Meet" allows him to have four-eyes meeting in few social gatherings with his Facebook friends. Now, with more than a million followers at Facebook and Twitter, Najib is the most popular figure in Malaysian cyberspace. Najib's significant contribution in social media was recognized with an award presented by Malaysian media practitioners in late 2013. Consequently, the other BN leaders have emulated Najib's approach of using social media to engage the people.

In contrast to the friendly and approachable images projected by the state leaders, the "cybertroopers" of BN (to be specific; UMNO, or United Malays National Organization, the largest party in BN coalition) have been adopting provocative-style writings and communication at social media. The cybertroopers have been using threats, intimidation, character assassination, manipulation of religion and racial sentiments, and prefer to use degrading and derogative words. The other objective of deploying cybertroopers is to balancing the temperature of social media which has "natural" tendency of opposing and dissenting the state.

In the GE-13, BN has committed itself to grandeur-style political campaign exercises. The fact is that the state has undertaken political marketing exercise years before the GE-13 via the umbrella of "1Malaysia" transformational program. A political analyst from National University of Singapore (NUS), Bridget Welsh claimed, to win the GE-13 the state has spent the total amount of RM57.7 million (Welsh 2013). The figure was extracted from her observation unto four thousand media reports from 2009 until April 2013. Meanwhile, Nielsen Media Research reported the Prime Minister Department expenses for advertisement (which include marketing in social media) in March 2013 was RM67.8 million (Zurairi 2013). The figure exceeded total spending by companies like Nestle and Unilever. The participation of the state in social media in the verge of the GE-13 was not only done through the usual (relatively cheap) engaging efforts, but also through advertising (which is exorbitantly expensive). The aggressive campaigns in social media are based on the "BetterNation" theme. Zurairi (2013) explained BN's twitter account “@barisanasional” has been under "promoted account" status since May 2013. To promote a 
Twitter account; which is depending on the frequency of promotion; a minimum cost for a month is USD15 thousand (RM45.9 thousand). There were many other kind of political marketing exercises in social media, for example the banners and the commercials which were strategically place all over the Net. In addition, almost all the political songs and political advertisements that appeared on TV or radio were also watchable on the Internet, especially at YouTube.

\section{Conclusion}

The result of GE-12 is the outcome of the absence of the state in social media. Meanwhile, the result of GE-13 is the yield of the active presence of the state in social media. The first analysis towards the findings (the result of GE-13) is grounded on the proposition that $\mathrm{BN}$ is the proponent of strong government that operates on race-based politics, and PR is the proponent of democratization which is free from race-based politics. Thus, the result of GE-13 indicates that the multi-racial urban dwellers who are well-exposed to social media have voted for democratization. It seems the state participation in social media failed to deliver the anticipated result. $\mathrm{BN}$ only managed to win with a simple majority; won the number of seats but loss in terms of popular votes. If the GE-13 was a presidential election, Anwar has already been occupying the office in Putrajaya. Hence, the participation of the state in social media failed to promote de-democratization, and social media is not like the traditional media. The interactive-ness, user-centered, and the almost-anarchic features of social media are the main factor to the failure of the state from dominating the cyberspace and build strong influence among the audience of social media.

However, the success of UMNO to add more seats, and the failure of the other $\mathrm{BN}$ component parties especially MCA (Malaysian Chinese Association) to retain seats raised the need for a different analysis. The finding states Malaysia has racially polarized. The Malays and the Bumiputera (the indigenous) of Sabah and Sarawak opted to status-quo, and the non-Bumiputera chose democratization. There are two conditions to be considered. The first condition is a better level of the Internet penetration. In comparison to 2008, Malaysians in 2013 have enjoyed better Internet access; better coverage; better devices. The second one is the success of BN (UMNO to be specific) recaptured the state of Kedah and Perak. In view of that, the state has successfully utilized social media to its advantage; and social media is just like the traditional media. The political contents those filling in the newspapers, radio, and television are also evidently relevant to social media.

Consequently, the other questions arise. Are the Chinese voters who voted for PR really wanted democracy? Are the urban and educated Malay voters who voted for PR really 
believed in democracy? In the verge of GE13, both coalitions, $\mathrm{BN}$ and $\mathrm{PR}$ have been abusing the term "change" as their core rhetoric. Both coalitions have identified themselves as the advocates of democracy and good-governance, and henceforth strongly believed in democratization. They promised to further vertically and horizontally transform and reform the nation. However, further investigation and analysis over the activities online and offline of both sides lead to different findings. On the surface, both are pursuing democratic agenda, but in another dimension, both have been entrapped by racebase politics and embracing similar political strategies. $\mathrm{BN}$ is not the only party that possesses cybertroopers. PR has been depending on keyboard warriors long before $\mathrm{BN}$ did. The main difference; ones are employed and the other ones are volunteers. However, both sides have been emulating similar strategies and communication styles like; playing racial cards, exploiting religious sentiments, spinning of facts and figures, and relying on character assassination. Hence, both are Machiavellians, and both are multifaceted. In other words, both coalitions; all main component parties of $\mathrm{BN}$ and $\mathrm{PR}$ are still bound to race-based politics. To answer the arisen questions; Chinese prefer democratization because it may open more economic opportunities with the relaxation of affirmative policies; meanwhile, the Malays, specifically the Islamists perceive democratization opens doors to a creation of Islamic state that further enhancing and expanding the role of state than limiting it. However, members of both races, especially the educated agreed on the need for goodgovernance. Islam promotes good-governance that opens economic opportunities for all.

Jesudason (1996) described Malaysia a syncretic state due to its conflicting behavior. Adapting from the said model, Heufers (2002:40) summarized Malaysia operates at multi-dimensional level; mixing coercive elements with electoral and democratic procedures; propagates religion while pursuing secular goals; engages in ethnic mobilization while inculcating national feelings. Therefore, the analysis of GE-13 has provided a finding that the state is not the only syncretic actor in Malaysia. The state, the oppositions, and the voters have been facing the dilemma between race and nation. Thus, Malaysia can be described as a syncretic society. The future of democracy is still bleak when racial identity is still crucial in the society. Moreover, Malaysians attitude towards democracy is resonant with the other Asian societies. Deviating from the West, citizens of Asian countries tend to think of democracy in substantive term and less in procedural term which makes less critical to the incumbent (Min-Hua, Yun-han, \& Yu-tzung 2013:168169). Theoretically, the need for regime change or democratization will exhibit when the repressive capacity of the state lies above 
certain threshold; in other words; the regime is too autocratic (Blaydes \& Lo 2011:134). However, the probability of democratization is minimal in highly polarized societies (Huntington 1984:214-215). Furthermore, the heterogeneity of Malaysian society mirrors the diversity of ex-Yugoslav states, or a "faultlines" society. Fault line is a concept within a paradigm of the clash of the civilizations; fault line societies have high potentials for internal conflicts due to its religious-based heterogeneity (Huntington 1997).

In conclusion, the de-democratization is an anticipated outcome when the state actively participates in social media as showcased by the GE-13 in Malaysia. However, the situation may only be arisen or limited to highly polarized societies (like multi -cultural societies that have been used to racebased politics and strong government). The state participation in social media may produce different result if adapts to homogeneous societies. Hence, the social media can be very effective to any users including the state. What matters are suitable techniques, good strategies, and right approaches are being applied to attract the target audiences. Thus, the extraordinary traits of social media do not make it too special for democratization nor dedemocratization. There have been many democratization and de-democratization which have been taken place around the world in the absence of social media. 


\section{References}

Anderson, B. (1983). Imagined communities: Reflections on the origin and spread of nationalism. London: Verso.

Blaydes, L. \& Lo, J. (2011). One man, one vote, one time? A model of democratization in the Middle East. Journal of Theoretical Politics 24(1), 110-146. doi: $10.1177 / 0951629811423121$

Beers, D. (2006). The public sphere and online, independent journalism. Canadian Journal of Education 29(1), 109-130.

Bellin, E. (2004). The robustness of authoritarianism in the Middle East: Exceptionalism in comparative perspective. Comparative Politics 36, 139-157.

Case, W. (1993). Semi-democracy in Malaysia: Withstanding the pressure for regime change. Pacific Affairs 66(2).

Crouch, H. (1996). Government \& society in Malaysia. St. Leornads: Allen \& Unwin.

Fischer, J. (2009). 'We shift channel when Mahathir appears': The political Internet and censorship in Malaysia. Akademika Journal of the Southeast Asia Social Science and Humanities 75. 43 $-64$.

Gershman, H. (2011). The fourth wave. National Endowment for Democracy.

Heufers, R. (2002). The politics of democracy in Malaysia. ASIEN 85. 39-60.

Huntington, S. P. (1984). Will more countries become democratic? Political Science Quarterly 99 (2), 193-218.

Huntington, S. P. (1997). The clash of civilizations and the remaking of world order. New York: Touchstone Books.

Jesudason, V. (1995). Statist democracy and the limits to civil society in Malaysia. The Journal of Commonwealth \& Comparative Politics 33(3), 335-356. 
Jesudason, V. (1996). The syncretic state and the restructuring of oppositional politics in Malaysia. In Rodan, G. (ed.), Political opposition in industrializing Asia. 128-160. London: Routledge.

Kua, A. (1995). Authoritarian populism. London: MacMillan.

Kukeyeva, F., \& Shkapyak, O. (2013). Central Asia's transition to democracy. Procedia - Social and Behavioral Sciences 81. 79-83.

Leo Agustino. 2013. Pendemokrasian di Indonesia: Kelahiran, penyebaran dan kematangan kesedaran politik. Bangi: UKM Press.

Mauzy, D. K. (1995). Malay political hegemony and 'coercive consociationalism'. In Mc Garry, J. \& O' Leary, B. (Ed.), The politics of ethnic regulation: Case studies of protracted ethnic conflicts. London: Routledge.

Min-Hua, H., Yun-han, C., \& Yu-tzung, C. (2013). Popular understanding of democracy and regime legitimacy in East Asia. Taiwan Journal of Democracy 9(1), 147-171.

Mohd Azizudin, M. S. (2010), Freedom of political speech and social responsibility in Malaysia. Bangi: Penerbit Universiti Kebangsaan Malaysia.

Mohd Azizudin, M. S., Zengeni, K. T. (2010). Democratisation in Malaysia: The impact of social media in the 2008 General Election. The paper presented at The $18^{\text {th }}$ Biennial Conference of the Asian Studies Association of Australia, Adelaide, 5-8 July.

Shirazi, F. (2010). The emancipatory role of information and communication technology: A case study of internet content filtering within Iran. Journal of Information, Communication \& Ethics in Society 8(1), 57-84. doi: 10.1108/14779961011024819

Sity, D. (2004). Globalisai dan negara pembangunan. Akademika Journal of the Southeast Asia Social Science and Humanities 64, 27-42.

Stepan, A. \& Linz, J. J. (2013). Democratization theory and the "Arab Spring". Journal of Democracy 24, 15-30.

Tan, L. O. (2010). Dinamik ruang siber dalam gerakan reformasi di Malaysia. Bangi: Penerbit Universiti Kebangsaan Malaysia.

Touri, M. (2009). News blogs: Strengthening democracy through conflict prevention. Aslib Proceedings: New Information Perspectives 61(2), 170-184. doi: 10.1108/00012530910946910

Von Vorys, K. (1975). Democracy without consensus: Communalism and political stability in Malaysia. Princeton: Princeton University Press.

Welsh, B. (2013). Buying support-Najib's 'commercialisation' of GE13. Retrieved from http:// www.malaysiakini.com/news/227713

Zakaria, A. (1989). Malaysia: Quasi-democracy in a divided society. In Diamond, L., Linz, J. J., \& Lipset, M. S., (Ed.), Democracy in developing countries: Asia. Colorado: Lynne Rienner.

Zurairi, A. (2013). BN berbelanja besar untuk kuasi ruang iklan. Retrieved from http:// www.themalaysianinsider.com/litee/print/bahasa/bn-berbelanja-besar-untuk-kuasai-ruangiklan/ 